\begin{tabular}{|c|c|}
\hline (5) & Malaysian Journal of Social Sciences and Humanities (MJSSH) \\
\hline Malaysian Journal of & Volume 5, Issue 9, September 2020 \\
\hline (MJ - sst) & e-ISSN : 2504-8562 \\
\hline & $\begin{array}{l}\text { Journal home page: } \\
\text { www.msocialsciences.com }\end{array}$ \\
\hline
\end{tabular}

\title{
Faktor Tingkah Laku Pelajar, Kekangan Masa, Beban Tugas dan Tekanan Kerja Dalam Kalangan Guru
}

\author{
Suhaimi Bin Kamarudin'1, Muhamad Suhaimi Taat ${ }^{1}$ \\ 1Fakulti Psikologi dan Pendidikan \\ Univerisiti Malaysia Sabah (UMS)
}

Correspondence: Suhaimi Bin Kamarudin (mie2421@gmail.com)

\begin{abstract}
Abstrak
Tekanan kerja merujuk kepada tindak balas atau reaksi fisiologi dan psikologi terhadap situasi atau keadaan persekitaran organisasi yang dipengaruhi oleh beberapa faktor dalaman dan luaran sehingga mewujudkan rangsangan negatif terhadap tahap kesihatan dan tingkah laku individu. Kajian ini dijalankan adalah bagi menentukan hubungan faktor tingkah laku pelajar, kekangan masa, beban tugas dengan tekanan kerja guru yang mengajar di kawasan bandar dan luar bandar di Sabah. Kajian juga bertujuan bagi mengenal pasti perbezaan tahap tekanan kerja berdasarkan ciri demografi iaitu lokasi sekolah dan jantina guru. Seramai 350 orang guru telah dipilih bagi mewakili populasi dengan menggunakan kaedah pensampelan rawak berstrata dan rawak mudah. Instrumen kajian diadaptasi daripada Teacher Stress Inventory (TSI) yang dbina oleh Boyle, Borg, Falzon dan Baglioni (1995) dan Fimian (1988). Hasil kajian mendapati bahawa kesemua faktor pemboleh ubah yang dinyatakan mempunyai hubungan yang signifikan dengan tekanan kerja. Selain itu, dapatan kajian juga menunjukkan guru yang mengajar di kawasan bandar dan luar bandar masing-masing mengalami tahap tekanan kerja yang rendah, manakala guru perempuan dilihat lebih berisiko mengalami tahap tekanan kerja yang tinggi berbanding guru lelaki.
\end{abstract}

Kata kunci: tekanan, tingkah laku pelajar, kekangan, beban tugas

\section{Student Behavior Factors, Time Constraints, Workload and Work Stress Among Teachers}

\begin{abstract}
Work stress refers to the physiological and psychological responses or reactions to the situation or state of the organizational environment that are influenced by several internal and external factors thus creating a negative stimulus to an individual's level of health and behavior. The study conducted to determine the relationship between student behavior factors, time constraints, workload and work stress of teachers who teach in urban and rural areas in Sabah. The study also aims to identify differences in the level of work stress based on demographic characteristics of school location and teacher gender. A total of 350 teachers were selected to represent the population using stratified and simple random sampling methods. The research instrument was adapted from the Teacher Stress Inventory (TSI) developed by Boyle, Borg, Falzon and Baglioni (1995) and Fimian (1988). The results of the study found that all of the stated variable factors have a significant relationship with work stress. In addition, the findings of the study also show that teachers who teach in urban and rural areas each have a low
\end{abstract}


level of work stress, while female teachers are seen to be more at risk of experiencing a high level of work stress than male teachers.

Keywords: stress, student behavior, constraints, workload

\section{Pengenalan}

Kenyataan yang dikeluarkan oleh Pertubuhan Kesihatan Sedunia (WHO), masalah tekanan di tempat kerja menjadi antara kebimbangan utama kepada tahap kesihatan individu dan diklasifikasi sebagai epidemik kesihatan menjelang abad ke-21 (Fink, 2016). Kementerian Kesihatan Malaysia turut menyuarakan kebimbangan terhadap fenomena yang berlaku dengan kemungkinan lebih ramai rakyat Malaysia akan berdepan dengan masalah kesihatan mental seperti kemurungan dan tekanan di tempat kerja disebabkan oleh pelbagai faktor persekitaran (Mallow, 2016). Dunia moden pada masa kini turut dilabel sebagai dunia yang diwarnai dengan tekanan kerja kepada manusia dengan segala macam keperluan dan kehendak yang perlu dipenuhi, persaingan, permintaan, tuntutan tugas, tanggungjawab, pelbagai kekangan, ketidakpastian masa depan, sokongan sosial dan konflik terhadap persekitaran organisasi. Dasawarsa, profesion keguruan dilihat antara bidang kerjaya paling berisiko mengalami tekanan kerja apabila seringkali berhadapan dengan pelbagai perubahan dan cabaran semasa dunia pendidikan termasuk perubahan dalam dasar kurikulum kebangsaan, pentaksiran dan penilaian, teknologi maklumat, bebanan tugas, tingkah laku pelajar, kekangan masa dan pelbagai masalah dalam persekitaran organisasi. Menurut S. dan Dawn (2015), Mathew (2011), Chaplain (2008), Kyriacou, (2001) kerjaya sebagai pendidik dianggap sebagai kerja yang berisiko mengalami tekanan sehingga memberi implikasi kepada tahap kesihatan dan kesejahteraan diri.. Ini dibuktikan dengan beberapa kajian yang dilakukan sama ada dari dalam dan luar negara bahawa kerjaya sebagai pendidik antara kerjaya yang paling berisiko mengalami tekanan kerja antaranya kajian oleh The American Institute of Stress pada tahun 2019 membuktikan bahawa profesion sebagai guru adalah profesion yang paling tertekan dengan pelbagai cabaran semasa sehingga membawa kepada risiko masalah kesihatan yang serius.. Ketekalan terhadap senario yang berlaku turut dibuktikan dengan statistik kajian oleh Universiti Putra Malaysia seramai 71.1 peratus guru di kawasan Lembah Klang mengalami masalah berkaitan tekanan kerja disebabkan oleh pelbagai faktor persekitaran (Amin, Amir, \& Ismail, 2019). Statistik oleh Kementerian Pendidikan Malaysia turut menunjukkan sejumlah 4.4 peratus atau 2123 daripada 48, 258 warga pendidik telah dikenal pasti mengalami tekanan kerja pada tahap sederhana dan tinggi disebabkan oleh pelbagai faktor persekitaran (Berita Harian, 2018).

Tekanan kerja telah menjadi satu fenomena dalam profesion keguruan pada masa kini disebabkan oleh pelbagai perubahan dalam senario pendidikan semasa, bukan sahaja di Malaysia bahkan di seluruh pelusuk dunia. Sebahagian besar adalah disebabkan oleh faktor persekitaran organisasi, dasardasar baharu dalam pendidikan, masalah dalaman individu dan peningkatan pelbagai bebanan tugas sampingan sehingga melangkaui fokus dan justifikasi terhadap tugas utama iaitu menyediakan pengajaran dan pembelajaran. Menurut He et.al (2002), tekanan kerja secara khususnya adalah tindak balas atau rangsangan tubuh badan secara tidak spesifik terhadap aspek psikologi dan fisiologi serta mewujudkan implikasi negatif terhadap kesihatan individu seperti simptom sakit kepala, sakit belakang, sakit pada leher, otot dan tekanan darah tinggi, emosi yang tidak stabil, perasaan marah (Mojoyinola, 2008; de Nobile \& McCormick, 2010; Mohd Shahril 2013). Perspektif yang diutarakan oleh Barouch Gilbert, Adesope, dan Schroeder (2014), Larchik dan Chance (2002), tekanan kerja yang dialami turut mempengaruhi secara dominan terhadap tingkah laku individu seperti prestasi dan kualiti kerja yang rendah, kepuasan kerja, masalah ketidakhadiran, bersikap sambil lewa terhadap tugas, kesan terhadap aspek fizikal seperti pening kepala, gangguan tidur, tekanan darah tinggi, penyakit jantung, seterusnya turut mempengaruhi terhadap tahap kesihatan aspek psikologi seperti masalah kemurungan, kebimbangan dan gangguan jiwa. 


\section{Pernyataan Masalah Kajian}

Polemik terhadap masalah tekanan kerja dalam konteks di Malaysia, melalui laporan Kesatuan Perkhidmatan Perguruan Kebangsaan (NUTP) pada tahun 2005 telah menunjukkan bilangan warga pendidik di seluruh negara bekerja dalam keadaan yang tertekan (Utusan Malaysia, 2006). Kajian oleh Kesatuan Perkhidmatan Perguruan Kebangsaan (NUTP) pula mendapati 70 peratus daripada 9,000 guru di seluruh negara tertekan bukan sahaja kerana bebanan tugas guru tetapi juga terpaksa berdepan dengan karenah di persekitaran tempat kerja (Ummi Kalsom, 2014). Senario semasa menunjukkan profesion perguruan berdepan dengan pelbagai tugas dan tanggungjawab yang perlu dilaksanakan seperti menyediakan rancangan pengajaran, melaksanakan aktivirti pengajaran dan pembelajaran, menyedia bahan bantu mengajar, menjalankan tugas-tugas perkeranian organisasi, dan juga menjalankan tugas-tugas harian seperti menghadiri bengkel, mesyuarat. Hal keadaan yang berlaku sememangnya memberi implikasi dan risiko kepada masalah kesihatan dan kesejahteraan mental dan fizikal guru. Kajian melibatkan beberapa faktor tekanan kerja yang paling berpengaruh seperti kajian Kokkinos (2007), Mearsn dan Cain (2003), Azizi Haji Yahaya, dan Shahrin Hashim, (2006), Kamaruzaman (2007), Kerr et.al (2011), Mohamed dan Nurul (2013), Mohd Zuri Ghani, Ahmad, \& Ibrahim (2014) mendapati faktor tingkah laku pelajar mempunyai hubungan dengan tekanan kerja. Tingkah laku pelajar menurut Reed dan Kirkpatrikck (1998) melibatkan tingkah laku menggangu, membuat bising di dalam kelas, tidak menyiapkan kerja, menggangu aktiviti pengajaran di dalam kelas, membuat bising, manakala (Ho 2004), turut konsisten dengan mengemukakan bahawa tingkah laku pelajar melibatkan pelanggaran disiplin seperti vandalisme, buli, tidak menyiapkan kerja, membuat bising di dalam kelas, dan tidak menghormati guru. Kajian Chua (2004), Ishak (2004), Lemaire (2009), Kaur, (2011), Ismail (2012), De Simone et.al (2016) pula melihat faktor beban tugas merupakan faktor paling berpengaruh terhadap masalah tekanan kerja. Beban tugas merupakan skop kerja atau tanggungjawab yang mesti dilaksanakan merangkumi aktiviti dalam atau luar darjah diukur berdasarkan kekerapan jumlah masa yang diperuntukkan untuk menyelesaikannya (Ibrahim Jari, 2017). Selain itu, kajian Skaalvik \& S. Skaalvik (2011), Raja Maria (2011), Muhamad Abdillah dan Woo (2010), Hakanen, Bakker, \& Schaufeli, (2006) pula berbeza dapatan apabila mendapati faktor kekangan masa menjadi faktor paling utama terhadap masalah tekanan kerja. Manakala, menurut kajian Nur Izzaty, Azman, Mohamad Shahril Azwan, \& Sholihien (2015), tekanan kerja yang dialami adalah disebabkan oleh faktor objektif dan matlamat organisasi yang tidak jelas, arahan yang tidak sesuai, kepelbagaian skop dan tuntutan kerja.

Dapatan-dapatan yang dikemukakan menunjukkan hasil kajian yang tidak konsisten terhadap faktorfaktor tekanan kerja, antara persekitaran dan populasi yang berbeza, bertepatan dengan Michie (2002) tekanan kerja yang dialami adalah berbeza mengikut keadaan dan individu serta suasana sebenar persekitaran organisasi. Justeru, berdasarkan pelbagai variasi dapatan para sarjana yang dinyatakan, kajian yang dijalankan dilihat signifikan apabila memberi tumpuan kepada faktor-faktor yang diramalkan paling dominan mempunyai hubungan dengan tekanan kerja, khusus kepada warga pendidik di negeri Sabah. Aspek-aspek tersebut akan memberikan kesan terhadap profesionalisme guru termasuklah sikap akademik dan efikasi kendiri mereka (Muhamad Suhaimi \& Gladys, 2014). Apatah lagi, guru pada era ini dipertanggungjawabkan dengan pelbagai tugasan khususnya bagi pelaksanaan pengajaran abad ke-21 (Jaggil \& Muhamad Suhaimi, 2018).

Melalui analisis dan pemerhatian terhadap literatur yang telah dibincangkan, pengkaji melihat penyelidikan berkaitan faktor-faktor tekanan kerja, hubungan dan pengaruhnya dalam kalangan guru di peringkat global telah banyak dilakukan dan semakin mendapat perhatian. Walau bagaimanapun, penyelidikan di dalam negara pula dilihat masih kurang dijalankan (Ibrahim Jari, 2014). Kepelbagaian faktor yang dilihat mempengaruhi tekanan kerja memberi impak yang besar dalam dunia pendidikan sehingga memberikan kesan negatif kepada tahap kesihatan individu, kualiti dan prestasi kerjaya. Kebanyakan kajian yang telah dilakukan juga dilihat cenderung kepada kajian berkaitan faktor yang mempengaruhi tekanan kerja secara umum melibatkan kawasan di bandar sahaja seperti Kuala Lumpur, Johor Baharu dan bandar-bandar di Semenanjung Malaysia. Namun begitu, kajian yang hanya memfokuskan kepada beberapa faktor paling berpengaruh secara lebih terperinci antaranya, faktor tingkah laku pelajar, beban tugas dan kekangan masa serta melihat perbezaan berdasarkan aspek demografi iaitu lokasi dan jantina masih kurang di jalankan terutamanya di negeri Sabah. Suasana 
yang berlaku turut menimbulkan satu persoalan adakah wujud perbezaan persepsi tahap tekanan kerja antara guru yang mengajar di kawasan bandar dan luar bandar seterusnya antara guru lelaki dan perempuan. Sebagaimana menurut Oliff dan Vermetten (2013), Figueira et.al (2007), Bedard, Greif, dan Buckley (2004) tahap tekanan kerja yang dialami dalam kalangan warga pendidik adalah berbeza mengikut populasi, kawasan dan persekitaran organisasi

\section{Literatur Kajian}

Pelbagai kajian empirikal yang telah dijalankan oleh pengkaji bagi mengenal pasti faktor-faktor utama tekanan kerja dan tahap tekanan kerja yang dialami dalam kalangan guru. Kajian oleh Montgomery dan Rupp (2005) mendapati tiga faktor utama tekanan kerja iaitu tingkah laku pelajar, bebanan kerja dan sokongan daripada rakan sekerja, Van Dick dan Wagner (2001), Sliscovic dan Sersic (2011), faktor bebanan tugas, manakala Chaplain (1995) faktor pengajaran dan pembelajaran, karenah pelajar, beban tugas. Seterusnya, menurut Klassen dan Chiu (2010), Fun (2008), faktor tingkah laku pelajar, beban tugas, kekangan masa dan penghargaan, manakala Harmsen, Helms-Lorenz, Maulana, dan van Veen (2018), melihat aspek negatif tingkah laku pelajar secara signifikan mempunyai kaitan dengan emosi negatif, ketegangan dan rasa tidak puas hati. Selain itu, Aldrup et.al (2018), Collie, Shapka, \& Perry (2012), Geving (2007) dan Kamaruzzaman (2007) turut menyenaraikan faktor tingkah laku pelajar adalah faktor utama kepada masalah yang dialami. Seterusnya, kajian Kukner (2015), Kokkinos (2007), Mohamad Abdillah dan Woo (2008) mendapati bahawa faktor kekangan masa antara faktor peramal paling dominan terhadap tekanan kerja dalam kalangan guru. Kajian Fun (2008), pula menyenaraikan empat faktor paling berpengaruh terhadap tekanan kerja iaitu faktor karenah pelajar, bebanan tugas, kekangan masa dan faktor penghargaan, manakala Karaj dan Rapti (2016) dan Ekundayo dan Kolawole (2013) melihat faktor persekitaran kerja yang tidak kondusif, hubungan rakan sekerja dan masalah pembayaran gaji adalah penyebab utama kepada tekanan kerja. Dunham (1992) pula menyenaraikan lima faktor utama yang mempengaruhi tekanan kerja guru iaitu, salah laku pelajar, bebanan tugas, penghargaan, kekangan masa dan sumber serta hubungan interpersonal. Dalam pada itu menurut Mangkunegara (2008), beban kerja, faktor tekanan masa, pengawasan kualiti kerja, persekitaran organisasi, tuntutan kerja yang tidak sepadan dengan tanggungjawab, dan konflik kerjaya antara faktor penyebab kepada berlakunya tekanan kerja.

Ketidaktekalan literatur terhadap perbezaan tahap tekanan kerja berdasarkan ciri demografi yang dialami turut menjadi fokus utama bagi mengisi kelompangan kajian empirikal berkaitan lokasi sekolah dan jantina guru. Dapatan Fontana (1989) mendapati guru perempuan mengalami tekanan kerja yang tinggi berbanding guru lelaki, konsistensi dapatan turut disokong oleh kajian Om Prakash (2016), Samad et.al (2011), Hui dan Chan (2007), namun tidak selari dengan dapatan Chaplain (1995), Mondal, Shrestha dan Bhaila (2011) apabila mendapati guru lelaki dilihat lebih tertekan berbanding guru perempuan. Selain itu, perbincangan literatur berkaitan ciri lokasi turut diperdebatkan apabila terdapat beberapa kajian lepas menunjukkan guru yang mengajar di kawasan bandar mengalami tahap tekanan yang tinggi berbanding guru yang mengajar di kawasan luar bandar disebabkan oleh faktor beban tugas yang tinggi, menguruskan masalah tingkah laku pelajar (Liu \& Onwuegbuzie, 2012; Millicent dan Joanne 2010; Shernoff et.al 2011). Berbeza dapatan kajian oleh Smith dan Smith (2006), Skembi et.al (2015), Eres dan Atansoska (2011) apabila mendapati guru yang mengajar di kawasan luar bandar mengalami tekanan kerja yang lebih tinggi berbanding guru yang mengajar di kawasan bandar. Selain itu, dapatan B. dan Jayarama (2016), Ibrahim Jari (2017), Amal Hayati (2015), dilihat tidak selari apabila mendapati tidak terdapat perbezaan signifikan tahap tekanan kerja antara lokasi sekolah.

\section{Objektif Kajian}

Objektif kajian yang dilakukan adalah untuk:

i. Mengenal pasti hubungan faktor tingkah laku pelajar, kekangan masa dan beban tugas dengan tekanan kerja dalam kalangan guru.

ii. Mengenal pasti perbezaan tahap tekanan kerja berdasarkan ciri jantina guru dan lokasi sekolah. 


\section{Hipoteisis Kajian}

$\mathrm{Ho}^{1}$ Tidak terdapat hubungan yang signifikan antara tingkah laku pelajar dengan tekanan kerja dalam kalangan guru.

$\mathrm{Ho}^{2}$ Tidak terdapat hubungan yang signifikan antara kekangan masa dengan tekanan kerja dalam kalangan guru.

$\mathrm{Ho}^{3}$ Tidak terdapat hubungan yang signifikan antara beban tugas dengan tekanan kerja dalam kalangan guru.

$\mathrm{Ho}^{4}$ Tidak terdapat perbezaan yang signifikan tekanan kerja berdasarkan jantina

$\mathrm{Ho}^{5}$ Tidak terdapat perbezaan yang signifikan tekanan kerja berdasarkan lokasi sekolah

\section{Metodologi}

Menurut Kerlinger dan Lee (1999), salah satu tujuan menyediakan reka bentuk penyelidikan adalah untuk mencari jawapan kepada persoalan-persoalan penyelidikan. Penyelidikan ini dijalankan menggunakan reka bentuk kajian bukan eksperimen dengan kaedah tinjauan. Tumpuan kajian melibatkan guru sekolah menengah di daerah Kota Kinabalu mewakili kawasan bandar dan daerah Tambunan, Keningau dan Tenom mewakili kawasan luar bandar. Seramai 350 orang responden terlibat dalam kajian ini melibatkan 10 buah sekolah iaitu 5 buah sekolah di daerah Kota Kinabalu, 2 buah di daerah Tambunan, sebuah di daerah Keningau dan 2 buah di daerah Tenom mewakili kawasan luar bandar. Kaedah persampelan yang digunakan bagi pemilihan responden kajian ialah persampelan rawak berstrata dan persampelan rawak mudah. Alat pengukuran yang digunakan adalah set instrumen yang mempunyai empat komponen indikator iaitu bahagian $\mathrm{A}$, indikator berkaitan ciri Demografi, iaitu lokasi dan jantina guru, bahagian B, Faktor Tingkah Laku Pelajar, Bahagian C, Faktor Kekangan Masa, Bahagian D, Faktor Beban Tugas dan bahagian E, indikator Tekanan Kerja. Instrumen yang digunakan diadaptasi daripada Teachers Stress Inventory (TSI) yang dibangunkan oleh Fimian (1988) dan Boyle et.al (1995). Semua data yang telah diperoleh di analisis dengan menggunakan"Statistical Package For Social Sciences" (SPSS V. 22.0 For Windows). Analisis pengujian Korelasi Pearson dan Ujian-t diaplikasi bagi tujuan menganalisis data yang diperlukan.

\section{Dapatan Kajian}

\section{Profil Responden}

Jadual 1 menunjukkan jumlah bilangan responden yang terlibat dalam kajian ini terdiri daripada guru lelaki seramai $105(30 \%)$ dan guru perempuan seramai 245 orang $(70 \%)$.

Jadual 1:Profil Responden

\begin{tabular}{lll}
\hline Profil Responden Jantina & Bilangan & Peratusan \\
\hline Lelaki & 105 & $30 \%$ \\
Perempuan & 245 & $70 \%$ \\
\hline
\end{tabular}

Jadual 2 menunjukkan taburan lokasi sekolah yang terlibat dalam kajian ini, terdiri daripada 190 buah dari kawasan bandar dan sejumlah 160 buah sekolah dari kawasan luar bandar.

Jadual 2: Lokasi Sekolah

\begin{tabular}{lll}
\hline Profil Lokasi Sekolah & Bilangan & Peratusan
\end{tabular}


DOI: https://doi.org/10.47405/mjssh.v5i9.481

\begin{tabular}{lll}
\hline Kawasan Bandar & 190 & $54 \%$ \\
\hline
\end{tabular}

\section{Hubungan Antara Faktor Tingkah Laku Pelajar Dengan Tekanan Kerja}

Keputusan analisis Korelasi Pearson menunjukkan faktor tingkah laku pelajar mempunyai hubungan positif dan signifikan dengan tekanan kerja dalam kalangan guru. Maka Hol adalah ditolak.

Jadual 3: Hubungan Faktor Tingkah Laku Pelajar dengan Tekanan Kerja

\begin{tabular}{lllll}
\hline \multirow{2}{*}{$\begin{array}{l}\text { Pemboleh } \\
\text { Ubah }\end{array}$} & \multicolumn{2}{l}{ Tekanan Kerja } & $\begin{array}{l}\text { Tahap } \\
\text { Hubungan }\end{array}$ & Keputusan \\
\cline { 2 - 5 } & $\begin{array}{l}\text { Nilai } \\
\text { Korelasi }\end{array}$ & $\begin{array}{l}\text { Nilai } \\
\text { Signifikan }\end{array}$ & \\
$\begin{array}{l}\text { Faktor Tingkah } \\
\text { Laku Pelajar }\end{array}$ & $.507^{* *}$ & .000 & Tinggi / Positif & Signifikan \\
\hline
\end{tabular}

\section{Hubungan Antara Faktor Kekangan Masa Dengan Tekanan Kerja}

Keputusan analisis Korelasi Pearson menunjukkan faktor kekangan masa mempunyai hubungan positif dan signifikan dengan tekanan kerja dalam kalangan guru. Maka Ho2 adalah ditolak.

Jadual 4: Hubungan Faktor Kekangan Masa dengan Tekanan Kerja

\begin{tabular}{lllll}
\hline \multirow{2}{*}{$\begin{array}{l}\text { Pemboleh } \\
\text { Ubah }\end{array}$} & \multicolumn{2}{l}{ Tekanan Kerja } & $\begin{array}{l}\text { Tahap } \\
\text { Hubungan }\end{array}$ & Keputusan \\
\cline { 2 - 5 } & $\begin{array}{l}\text { Nilai } \\
\text { Korelasi }\end{array}$ & $\begin{array}{l}\text { Nilai } \\
\text { Signifikan }\end{array}$ & \\
\hline $\begin{array}{l}\text { Faktor } \\
\text { Kekangan Masa }\end{array}$ & $.562^{* *}$ & .000 & $\begin{array}{l}\text { Sederhana / } \\
\text { Positif }\end{array}$ & Signifikan \\
\hline
\end{tabular}

\section{Hubungan Antara Beban Tugas Dengan Tekanan Kerja}

Keputusan analisis Korelasi Pearson menunjukkan faktor beban tugas mempunyai hubungan positif dan signifikan dengan tekanan kerja dalam kalangan guru. Maka Ho3 adalah ditolak.

Jadual 5: Hubungan Faktor Beban Tugas dengan Tekanan Kerja

\begin{tabular}{lllll}
\hline \multirow{2}{*}{ Pemboleh Ubah } & \multicolumn{2}{l}{ Tekanan Kerja } & \multicolumn{1}{l}{$\begin{array}{l}\text { Tahap } \\
\text { Hubungan }\end{array}$} & Keputusan \\
\cline { 2 - 5 } & $\begin{array}{l}\text { Nilai } \\
\text { Korelasi }\end{array}$ & $\begin{array}{l}\text { Nilai } \\
\text { Signifikan }\end{array}$ & \\
$\begin{array}{l}\text { Faktor Beban } \\
\text { Tugas }\end{array}$ & $.374^{* *}$ & .000 & Rendah / Positif & Signifikan \\
\hline
\end{tabular}

\section{Perbezaan Tahap Tekanan Kerja Berdasarkan Lokasi}

Berdasarkan dapatan analisis Jadual 6, dapatan menunjukkan tidak terdapat perbezaan yang signifikan tahap tekanan kerja berdasarkan lokasi sekolah. Maka Ho4 adalah gagal ditolak. 
DOI: https://doi.org/10.47405/mjssh.v5i9.481

Jadual 6: Analisis Ujian -t Tahap Tekanan Kerja Berdasarkan Lokasi

\begin{tabular}{lllllll}
\hline Lokasi & Jumlah & Min & SP & Nilai-t & dk & Sig \\
\hline Bandar & 190 & 2.00 & 0.67 & & & \\
Luar Bandar & 160 & 2.00 & 0.66 & -0.038 & 348 & 0.097 \\
\hline
\end{tabular}

\section{Perbezaan Tahap Tekanan Kerja Berdasarkan Jantina}

Analisis Jadual 7 menunjukkan perbezaan tahap tekanan kerja berdasarkan ciri demografi jantina. Dapatan kajian menunjukkan terdapat perbezaan yang signifikan skor min tahap tekanan kerja berdasarkan jantina guru. Maka Ho5 adalah ditolak.

Jadual 7: Analisis Ujian -t Tahap Tekanan Kerja Berdasarkan Jantina

\begin{tabular}{lllllll}
\hline Jantina & Jumlah & Min & SP & Nilai-t & dk & Sig \\
\hline Lelaki & 105 & 1.85 & 0.61 & & & \\
& & & & -2.70 & 348 & 0.007 \\
Perempuan & 245 & 2.06 & 0.68 & & & \\
\hline
\end{tabular}

\section{Perbincangan}

Perbincangan analisis kajian seterusnya adalah bertujuan melihat hubungan faktor peramal tekanan kerja iaitu faktor tingkah laku pelajar, kekangan masa, dan beban tugas terhadap tekanan kerja. Hasil dapatan kajian yang diperoleh menunjukkan bahawa terdapat hubungan yang signifikan dan positif antara faktor tingkah laku pelajar, kekangan masa, dan beban tugas dengan tekanan kerja dari kesemua aspek tekanan kerja. Analisis kajian secara keseluruhan menunjukkan hubungan faktor tingkah laku pelajar dan kekangan masa terhadap tekanan kerja berada pada tahap hubungan yang sederhana, manakala, bagi faktor beban tugas, hubungan berada pada tahap yang rendah terhadap tekanan kerja. Dapatan kajian turut memberi petunjuk bahawa faktor kekangan masa mempunyai hubungan paling dominan terhadap tekanan kerja berbanding dengan faktor-faktor tekanan yang dinyatakan.

Hasil dapatan kajian yang dijalankan adalah sependapat dan menyokong dapatan Karaj dan Rapti (2013), Zedan (2012), Dumitru dan Ioan (2012), Kokkinos (2007), Kamaruzzaman (2007), Geving (2007), Thomas, Clarke dan Layery (2003), Kyriacou (2001), Boyle et.al (1988), di mana, kesemua pemboleh ubah peramal terhadap tekanan kerja mempunyai hubungan yang signifikan dengan tekanan kerja guru. seterusnya hubungan tinggi dan kuat antara tingkah laku pelajar dan beban tugas terhadap tekanan kerja (Abdul Said Ambotang, Norazizah Pilus, 2014). Sementara itu, kajian Noraini (2015), turut melaporkan bahawa faktor kekangan masa dan tingkah laku pelajar mempunyai hubungan signifikan dengan masalah tekanan kerja.. Selain itu, konsistensi dapatan turut disokong oleh Suarthana dan Riana (2016), Haryanti, Aini, dan Purwaningsih (2013), terdapat hubungan positif antara beban tugas dengan tekanan kerja dan secara keseluruhannya, hasil dapatan kajian memberikan bukti yang jelas bahawa kesemua faktor peramal yang dinyatakan mempunyai hubungan yang signifikan dengan masalah tekanan kerja dalam kalangan guru di negeri Sabah.

Secara signifikannya, konklusi hasil dapatan kajian memberi petunjuk bahawa guru-guru yang mengajar di sekolah sememangnya berhadapan dengan pelbagai masalah yang berkaitan dengan sikap dan tingkah laku pelajar melibatkan masalah disiplin, tahap motivasi yang rendah, penguasaan akademik yang lemah, kekangan terhadap peruntukan waktu yang agak terhad bagi perlaksanaan pelbagai aktiviti pengajaran dan pembelajaran di dalam dan luar kelas, terutama penyediaan rancangan pengajaran harian dan bahan bantu mengajar, menghabiskan sukatan pelajaran dan memeriksa buku latihan dan aktiviti pelajar. Selain itu, guru turut dibebani dengan pelbagai tugas dan tanggungjawab melibatkan kerja-kerja pentadbiran, merancang dan melaksanakan pelbagai program, selain 
menghadiri kursus dan bengkel sehingga menyebabkan guru terbeban dengan pelbagai tanggungjawab yang perlu diurus dan dilaksana dalam tempoh waktu yang agak terhad.

Hasil dapatan analisis kajian yang telah dibincangkan, berkaitan tahap tekanan kerja berdasarkan lokasi sekolah iaitu kawasan bandar dan luar bandar menunjukkan bahawa ciri demografi berdasarkan lokasi tidak memberikan persepsi yang berbeza terhadap masalah yang dialami. Analisis pengujian juga mendapati bahawa tidak terdapat perbezaan yang signifikan bagi kesemua faktor yang dinyatakan berdasarkan lokasi bandar dan luar bandar, begitu juga tahap tekanan kerja yang dialami. Dapatan kajian dilihat konsisten dengan kajian Prabhakara dan Jayamma (2016) bahawa tidak terdapat perbezaan tahap tekanan kerja antara guru sekolah menengah yang mengajar di kawasan bandar dan luar bandar. Dapatan kajian juga disokong oleh Ibrahim Jari (2017), Amal Hayati (2015). Walaubagaimanapun, dapatan tidak konsisten dengan Millicent dan Joanne (2010), Shernoff, Mehta, Atkins, Torf, dan Spencer (2011), Abel, Millicent, Sewell, Joanne (1999), guru-guru yang mengajar di kawasan bandar mengalami tahap tekanan kerja yang tinggi berbanding kawasan luar bandar. Secara keseluruhannya, kajian menunjukkan tidak terdapat perbezaan yang signifikan tahap tekanan kerja berdasarkan lokasi sekolah. Analisis dapatan kajian turut memberi petunjuk bahawa tahap tekanan kerja guru-guru yang mengajar di kawasan bandar dan luar bandar adalah pada tahap yang rendah.

Penelitian dapatan analisis seterusnya adalah berkaitan faktor-faktor peramal pemboleh ubah iaitu tingkah laku pelajar, kekangan masa, beban tugas dan tahap bagi pemboleh ubah endogen iaitu tekanan kerja berdasarkan ciri demografi jantina guru. Hasil kajian menunjukkan bahawa tiada perbezaan yang signifikan tahap faktor tekanan kerja antara guru lelaki dan perempuan bagi faktor tingkah laku pelajar dan beban tugas. Walaubagaimanapun, dapatan kajian terhadap faktor kekangan masa dan tahap tekanan kerja menunjukkan guru perempuan berhadapan dengan masalah berkaitan faktor peramal kekangan masa dan tekanan kerja yang lebih tinggi berbanding guru lelaki di sekolah. Dapatan kajian diperkukuhkan oleh Fontana (1989), guru perempuan mengalami tahap tekanan kerja yang lebih tinggi apabila terpaksa memperuntukkan penggunaan masa yang lebih banyak untuk melaksanakan tugas dan tanggungjawab yang diberikan selain berusaha meningkatkan kualiti dan prestasi kerja di sekolah. Konsistensi dapatan kajian turut di sokong oleh Farber (1991), Rohani (1991), Dua (1994), Chaplain (1995) Samad et.al (2011) dan Harmsen et.al (2018), dimana guru perempuan berisiko mengalami tekanan kerja berbanding guru lelaki. Dapatan kajian juga turut konsisten dengan Hui dan Chan (2007) melibatkan guru sekolah menengah di Hong Kong apabila mendapati guru perempuan mengalami tahap tekanan yang lebih tinggi berbanding guru lelaki akibat daripada masalah kekangan masa dan bebanan tugas yang tinggi.

Seterusnya, konsistensi dapatan kajian juga disokong oleh S. dan Dawn (2015), Hanif, Tariq, \& Masood (2011), Klassen dan Chiu (2010), Jepson dan Forest (2006), Phillips, Sen, dan McNamee (2007), Jarvis (2002), yang turut mendapati guru perempuan mengalami tahap tekanan kerja yang tinggi berbanding guru lelaki. Walau bagaimanapun, beberapa kajian lepas menunjukkan dapatan yang tidak konsisten dengan kajian ini, antaranya, Navidinia dan Heiran (2017), Ibrahim Jari (2014), Syed Sofian dan Rohany (2010), Tee dan Azizi (2006), Azizi Yahaya dan Jamaludin Ramli, (2010), Abdul Said Ambotang dan Muhamad Hisyam (2011) apabila mendapati tiada perbezaan yang signifikan tekanan kerja berdasarkan jantina guru.

Selain itu, beberapa kajian empirikal pula menunjukkan dapatan yang tidak konsisten dengan hasil kajian antaranya Aftab dan Khatoon (2012), Chaplain (1995), guru lelaki mengalami tahap tekanan yang lebih tinggi berbanding guru perempuan, namun berbeza dengan pandangan Dobson (1982), guru perempuan lebih tinggi tahap tekanan kerja akibat daripada faktor tingkah laku pelajar yang tidak berdisiplin, disokong oleh Jarvis (2002) dan Klassen (2010). Walau bagaimanapun, dapatan dilihat tidak selari dengan Fontana dan Abouserie (1993), guru lelaki lebih tertekan apabila berhadapan dengan masalah berkaitan tingkah laku pelajar, berbanding guru perempuan. Hasil dapatan kajian juga dilihat tidak konsisten dengan dapatan Fontana dan Abouserie (1993), Wan Mohammad (2002), Borg dan Riding (1991), Fimian (1988), di mana guru lelaki adalah lebih tertekan berbanding guru perempuan. Dapatan Antoniou et.al (2006), melihat ciri berkaitan jantina sememangnya memberi kesan terhadap tekanan kerja, guru perempuan mengalami tekanan kerja yang tinggi berbanding guru lelaki apabila berhadapan dengan suasana bilik darjah dan beban kerja yang tinggi, turut disokong oleh Klassen dan Chiu (2010) dan Kantas (2001). 


\section{Kesimpulan}

Hasil kajian menunjukkan bahawa kesemua faktor peramal pemboleh ubah tekanan kerja iaitu tingkah laku pelajar, kekangan masa dan beban tugas mempunyai hubungan positif dan signifikan terhadap tekanan kerja. Dapatan analisis yang diperoleh juga memberi petunjuk bahawa elemen faktor pemboleh ubah yang wujud daripada persekitaran kerja mempunyai hubungan terhadap masalah tekanan kerja yang dialami dalam profesion keguruan. Hubungan yang berlaku secara langsung sememangnya memberi kesan terhadap nilai akauntabiliti dan integriti profesionalisme serta kepercayaan masyarakat terhadap kerjaya yang diceburi. Justeru sebarang kewujudan elemen-elemen negatif dalam persekitaran pendidikan akan memberi impak terhadap usaha merealisasikan visi dan misi bagi membangunkan potensi individu demi pembangunan dan kejayaan masa depan negara yang lebih gemilang. Kajian diharapkan dapat memberi implikasi bernilai kepada pihak-pihak yang terlibat secara langsung atau tidak langsung dalam mencari solusi dan kaedah terbaik bagi mengawal dan menangani isu dan masalah yang dihadapi agar iklim dan persekitaran di sekolah dapat membantu guru melaksanakan tugas dan tanggungjawab secara lebif efektif dan berkualiti.

\section{Rujukan}

Abdul Said Ambotang, Norazizah Pilus, C. A. Q. A. (2014). Hubungan Karenah Pelajar Dan Beban Tugas Dengan Tahap Stres Guru Di Sekolah Menengah; Jurnal Kinabalu, 20. Retrieved from http://www.ums.edu.my/fksw/en/current-issue/125-hubungan-karenah-pelajar-dan-beban-tugasdengan-tahap-stres-guru-di-sekolah-menengah

Aftab, M., \& Khatoon, T. (2012). Demographic Differences and Occupational Stress of Secondary School Teachers. European Scientific Journal.

Amin, N. B., Amir, A. M., \& Ismail, S. F. (2019). Key Ferformance Indicators Tugas, Ganjaran Dan Prestasi Kerja Gru Di Sekolah Kerajaan. Jurnal Kepimpinan Pendidikan.

Antoniou, A. S., Polychroni, F., \& Vlachakis, A. N. (2006). Gender and age differences in occupational stress and professional burnout between primary and high-school teachers in Greece. Journal of Managerial Psychology. https://doi.org/10.1108/02683940610690213

Azizi Haji Yahaya, Shahrin Hashim, T. S. (1989). Occupational stress Among Technical teachers In Technical School in Johore, Malacca and Negeri Sembilan. Journal of Chemical Information and Modeling. https://doi.org/10.1017/CBO9781107415324.004

Azizi Yahaya, \& Jamaludin Ramli. (2010). Stres Dalam Kalangan Guru Sekolah Menengah Di Empat Buah Negeri Di Malaysia (Factors That Contributed Stress Among Secondary School Teachers in Four States in Malaysia). Asia Pacific Journal of Educators and Education, 25, 103-136.

Barouch Gilbert, R., Adesope, O. O., \& Schroeder, N. L. (2014). Efficacy beliefs, job satisfaction, stress and their influence on the occupational commitment of English-medium content teachers in the Dominican Republic. Educational Psychology. https://doi.org/10.1080/01443410.2013.814193

Bedard, M., Greif, J. L., \& Buckley, T. C. (2004). International publication trends in the traumatic stress literature. Journal of Traumatic Stress. https://doi.org/10.1023/B:JOTS.0000022615.03388.78

Borg, M. G., \& Riding, R. J. (1991). Towards a model for the determinants of occupational stress among schoolteachers. European Journal of Psychology of Education. https://doi.org/10.1007/BF03172771

Chaplain, R. P. (2008). Stress and psychological distress among trainee secondary teachers in England. Educational Psychology. https://doi.org/10.1080/01443410701491858

Collie, R. J., Shapka, J. D., \& Perry, N. E. (2012). School climate and social-emotional learning: Predicting teacher stress, job satisfaction, and teaching efficacy. Journal of Educational Psychology. https://doi.org/10.1037/a0029356

De Nobile, J. J., \& McCormick, J. (2010). Occupational stress of Catholic primary school staff: A study of biographical differences. International Journal of Educational Management. https://doi.org/10.1108/09513541011067674 
De Simone, S., Cicotto, G., \& Lampis, J. (2016). Occupational stress, job satisfaction and physical health in teachers. Revue Europeenne de Psychologie Appliquee, 66(2), 65-77. https://doi.org/10.1016/j.erap.2016.03.002

Dumitru, I., \& Talpos, I. (2012). Stress Factors in the Professional Activities of Romanian Teachers. Procedia - Social and Behavioral Sciences. https://doi.org/10.1016/j.sbspro.2012.09.577

Fimian, M. J. (1988). Predictors of classroom stress and burnout experienced by gifted and talented students. Psychology in the Schools. https://doi.org/10.1002/1520-6807(198810)25:4<392::AIDPITS2310250407>3.0.CO;2-D

Fink, G. (2016). Stress: Concepts, definition and history. In The Curated Reference Collection in Neuroscience and Biobehavioral Psychology. https://doi.org/10.1016/B978-0-12-8093245.02208-2

Fontana, D., \& Abouserie, R. (1993). Stress levels, gender and personality factors in teachers. British Journal of Educational Psychology. https://doi.org/10.1111/j.2044-8279.1993.tb01056.x

Ghani, M. Z., Ahmad, A. C., \& Ibrahim, S. (2014). Stress among Special Education Teachers in Malaysia. Procedia - Social and Behavioral Sciences. https://doi.org/10.1016/j.sbspro.2013.12.648

Hakanen, J. J., Bakker, A. B., \& Schaufeli, W. B. (2006). Burnout and work engagement among teachers. Journal of School Psychology. https://doi.org/10.1016/j.jsp.2005.11.001

Hanif, R., Tariq, S., \& Masood, N. (2011). Personal and Job Related Predictors of Teacher Stress and Job Performance among School Teachers. Pakistan Journal of Commerce \& Social Sciences.

Harmsen, R., Helms-Lorenz, M., Maulana, R., \& van Veen, K. (2018). The relationship between beginning teachers' stress causes, stress responses, teaching behaviour and attrition. Teachers and Teaching: Theory and Practice. https://doi.org/10.1080/13540602.2018.1465404

Haryanti, Aini, F., \& Purwaningsih, P. (2013). Hubungan Antara Beban Kerja Dengan Stres Kerja Perawat Di Instalasi Gawat Darurat Rsud Kabupaten Semarang. Jurnal Managemen Keperawatan, 1(1), 48-56

He, N., Zhao, J., \& Archbold, C. A. (2002). Gender and police stress: The convergent and divergent impact of work environment, work-family conflict, and stress coping mechanisms of female and male police officers. Policing. https://doi.org/10.1108/13639510210450631

Ho, I. T. (2004). A comparison of Australian and Chinese teachers' attributions for student problem behaviors. Educational Psychology. https://doi.org/10.1080/0144341042000211706

Jaggil Apak \& Muhamad Suhaimi Taat. (2018). Pengaruh Kesediaan Guru Terhadap Pengurusan Bilik Darjah Abad Ke-21. Malaysian Journal of Social Sciences and Humanities (MJSSH), 3(4), 6-22.

Kamaruddin, K. (2007). Tekanan Kerja di kalangan guru sekolah menengah. Jurnal Kemanusiaan, $10(1), 105-118$.

Kantas, A. (2001). Factors of stress and occupational burnout of teachers, in Vasilaki, E., Triliva, S. and Besevegis, kaiE. (Eds), Stress, Anxiety and Intervention, Ellinika Grammata, Athens, pp. 217-29.

Karaj, S., \& Rapti, E. (2013). Teacher Job Stress in Albania: Examining the Role of Students' Classroom Disruptive Behavior and other Factors in the School Context. Problems of Education in the 21 st Century.

Kaur, S. (2011). Comparative Study of Occupational Stress among Teachers of Private and Govt. Schools in Relation to their Age, Gender and Teaching Experience. International Journal of Educational Planning \& Administration. https://doi.org/10.1177/1362361307078130

Kerlinger, F. N., \& Lee, H. B. (1999). Research design: Purpose and principles. In Foundations of behavioral research.

Kerr, R. A., Kerr, R. A., Breen, J., Delaney, M., Kelly, C., \& Miller, K. (2011). A Qualitative Study of Workplace Stress and Coping in Secondary Teachers in Ireland. Irish Journal of Applies Social Studies. https://doi.org/10.21427/D7G72Q

Klassen, R. M., \& Chiu, M. M. (2010). Effects on Teachers' Self-Efficacy and Job Satisfaction: Teacher Gender, Years of Experience, and Job Stress. Journal of Educational Psychology, 102(3), 741-756. https://doi.org/10.1037/a0019237

Kokkinos, C. M. (2007). Job stressors, personality and burnout in primary school teachers. British Journal of Educational Psychology. https://doi.org/10.1348/000709905X90344

Kyriacou, C. (2001). Teacher stress: Directions for future research. Educational Review. Retrieved from http://www.tandfonline.com/doi/abs/10.1080/00131910120033628 
Lemaire, J. (2009). Addressing teacher workload. Education.

Mallow, M. S. (2016). Occupational Stress in Malaysia: Causes, Effects and Possible Solutions. Proceedings of SOCIOINT 2016 3rd International Conference on Education, Social Sciences and Humanities.

Michie, S. (2002). Causes and management of stress at work. Occupational and Environmental Medicine, 59(1), 67-72. https://doi.org/10.1136/oem.59.1.67

Muhamad Suhaimi Taat \& Gladys De Rozario. (2014). The Influence of Academic Attitude and SelfEfficacy Towards Students Achievement in Private Higher Learning Institution, Malaysia. International Journal of Arts and Commerce, 1, 41-50.

Mojoyinola, J. K. (2008). Effects of job stress on health, personal and work behaviour of nurses in public hospitals in Ibadan Metropolis, Nigeria. European Journal of Scientific Research. https://doi.org/10.1080/09735070.2008.11886326

Mondal, J., Shrestha, S., \& Bhaila, A. (2011). School teachers: Job stress and job satisfaction, Kaski, Nepal. International Journal of Occupational Safety and Health, 1, 27-33.

Navidinia. H., Heiran. A. (2017). Exploring the demographic and contextual factors influencing English language teachers' burnout: Implications for teachers' burnout. ASEAN Journal of Teaching \& Learning in Higher Education.

Nur Izzaty, M., Azman, I., Mohamad Shahril Azwan, M. R., \& Sholihien, A. (2015). Work stress and its relationship with workers' health: An empirical study of a police contingent in Peninsular Malaysia. GEOGRAFIA Online Malaysian Journal of Society and Space.

Phillips, S., Sen, D., \& McNamee, R. (2007). Prevalence and causes of self-reported work-related stress in head teachers. Occupational Medicine. https://doi.org/10.1093/occmed/kqm055

Raja Maria. (2011). Faktor-Faktor Yang Mendorong Tekanan Kerja ( Stres ) Di Kalangan Guru-Guru Sekolah Menengah Di Daerah Pasir Puteh. Master of Education Open University Malaysia 2011.

S., D., \& Dawn O. P., S. . S. (2015). Stress in school teachers of a school in west bengal, India. Indian Journal of Psychiatry.

Samad, N. I. A., Hashim, Z., Moin, S., \& Abdullah, H. (2011). Assessment of Stress and Its Risk Factors Among Primary School Teachers in the Klang Valley, Malaysia. Epidemiology. https://doi.org/10.1097/01.ede.0000392452.76957.b9

Siva Vikaraman, S., Norhaini Mansor, A., \& Izham Mohd Hamzah, M. (2018). Influence of Ethical Leadership Practices in Developing Trust in Leaders: a Pilot Study on Malaysian Secondary Schools. International Journal of Engineering \& Technology. https://doi.org/10.14419/ijet.v7i3.30.18348

Ummi Kalsom Zakaria (2014). Faktor-Faktor Yang Mempengaruhi Tekanan Kerja Dalam Kalangan Guru Sekolah Menengah Daerah Hulu Terengganu, Terengganu Darul Iman. Tesis Sarjana Universiti Utara Malaysia.

Van Dick, R., \& Wagner, U. (2001). Stress and strain in teaching: A structural equation approach. British Journal of Educational Psychology. https://doi.org/10.1348/000709901158505

Wan Mohamad Nasir Wan Abdul Rahman. (2002). Faktor-Faktor Stres Pekerjaan Pensyarah Politeknik: Satu Kajian Kes di Politeknik Sultan Abdul Halim Mu’adzam Shah.Tesis Sarjana. Universiti Utara Malaysia.

Zedan, R. 2012. Stress and Coping Strategies Among Elementary School Teachers in Israel. Universal Journal of Education and General Studies, 1(9) 265-278. 